\title{
Російська політична еміграція у Швейцарії в 1840-х рр.
} Коломоєць Ю. І. Дніпровський національний університет імені Олеся Гончара

В статті аналізується початок процесу формування у Швейцарії осередку російської політичної еміграції.

Ключові слова: Швейцарія; анархо-комунізм; еміграція

В статье анализируется начало процесса формирования в Швейцарии очага российской политической эмиграции.

Ключевые слова: Швейцария; анархо-коммунизм; эмиграция

1840s became a breakthrough in the history of the world revolutionary movement. It is at this time that the Russian revolutionary emigration begins its formation. From the beginning of the 1840s, future leaders of the radical branches in the liberation movement are beginning to arrive to Switzerland. The first was the founder and ideologue of the world's anarcho-communism, M. Bakunin, who arrived in Zurich, where he began his revolutionary activity. The political situation in the Russian Empire during the reign of Nicholas I forced the opposition-minded activists to leave the country with a view to continue the struggle against tsarism from abroad. Importance of Switzerland, as the center of concentration of the radical elements of the European revolutionary movement, particularly grew during and after the revolutions of 1848-1849. This country, which had the status of internationally recognized neutrality, could become a safe haven for revolutionaries who were forced to flee France, Germany, Austria and Italy.

In Switzerland, they were protected from extradition to their governments, they could enjoy freedoms that were based on a democratic system, feeling sympathetic to themselves from local socialists, influential in government circles. Russian emigrants also chose Switzerland as the main focus of their activities, which caused concern of the law enforcement authorities of the Russian Empire. Exactly in the 1840s was laid the foundation, which turns Switzerland into the center of Russian revolutionary emigration. Precisely in the 1840 s the struggle of the imperial law enforcement agencies with a revolutionary emigration began, reaching its peak before and during the revolution of 1905-1907. The experience of emigration was used by representatives of all the revolutionary forces of the Russian Empire, from the Narodniks to the Social-Democrats and Socialist-Revolutionaries. The activities of M. Bakunin and his followers showed the possible effectiveness of the influence of emigration on events within the country, forcing the tsarist government to take certain steps to stabilize the situation in the state, which became one of the most important reasons for reforms in the Russian Empire of the 1860s.

Keywords: Switzerland; anarcho-communism; emigration 
Ситуація, що складалася у Західній Європі протягом 40-х pp. XIX ст., завершилася революційними подіями у Франції, Австрійській імперії, Італії, Німеччині, які увійшли в історію під назвою «весна народів». Звичайно, що для Російської імперії епохи царювання Миколи I, надзвичайно важливим було не допустити в країні подібних подій. Перш за все, з точки зору царського уряду, було необхідно приховати від громадськості самі факти революційних виступів. Для цього Росія намагалася відгородитися стіною від Західної Свропи, встановлюючи певний інформаційний вакуум. Єдиними людьми, які були здатні побачити і оцінити, що відбувається в Свропі з точки зору російських реалій були політичні емігранти, змушені залишати батьківщину під загрозою переслідування з боку царських каральних органів.

Проте, слід відзначити, що до 1850-х рр., з нашої точки зору, не можна говорити про російську політичну еміграцію як соціальне явище. Еміграція 1820-1840-х рр. характеризувалася появою за кордоном окремих людей, які або змушені були переховуватися, або легально залишали Росію, мотивуючи це зовсім іншими причинами. Як зазначав відомий російський літературний і громадський діяч П. В. Анненков, «про російську політичну еміграцію не було ще й згадки: вона з'явилась тільки тоді, коли прокотився грім революції 1848 р. і змусив багатьох звернутися до свого минулого, підвести йому підсумки і поставити себе самого у зрозуміле, визначене становище як по відношенню до грізного явища, що несподівано прокотилося Європою, так і до урядів, які були ним налякані [1, с. 476]». Тим не менше саме з 1840-х рр., на нашу думку, починає виникати російська революційна еміграція, яка стає певним історичним феноменом вже на початку XX ст., коли за даними Департаменту поліції тільки в Західній Європі знаходилось більше 20 тисяч політичних емігрантів.

Звичайно, необхідно підкреслити, що еміграція з Росії як явище починає виникати ще у XVI ст., 3 часів утечі до Литви князя Курбського, який позиціонував себе в якості противника російського царя Івана Грозного. Але в наступні століття еміграція чітко не визначала свого більш менш масового політичного обличчя, залишаючись актами непокори окремих російських підданих. Вперше, 3 нашої точки зору, можна вести мову про політичну еміграцію як свідомо прийняте рішення з часів розгрому декабристського руху. Саме в цей момент учасники руху повинні були визначитися стосовно своєї подальшої долі: або втікати за кордон, або бути підданими кримінальному переслідуванню. Більшість декабристів вибрали 
друге, виходячи із солідарності з тими, хто вже був заарештований, але з'явилися й такі люди, як О. Остерман-Толстой або М. Тургенєв, що обрали еміграцію як засіб не тільки уникнення покарання, але й можливості тим чи іншим чином продовжувати свою діяльність.

Протягом 20-30-х pp. XIX ст. за кордон виїжджали люди, які внутрішньо були незгодні 3 існуючим у Росії режимом. Цей процес мав настільки поодинокий характер, що царська влада взагалі не реагувала на нього. Враховуючи сильні позиції слов'янофілів у російській громадській думці даного періоду, правохоронні органи не тільки практично не звертали уваги на виїжджаючих, але досить недбало ставились навіть до ввезення в Російську імперію закордонної літератури, яка інколи мала й революційне спрямування. Так, за даними історика О. Ніфонтова кількість іноземних книжок, ввезених у Росію, постійно збільшувалася. Якщо у 1846 р. було ввезено 547 тис. примірників, то у 1847 р. ця цифра сягнула 863 тис. О. Ніфонтов відзначав, що «треба сказати прямо - до подій 1848 р. спостреження за ввезенням заборонених видань проводилося недбало. Проникнення в Росію нелегальної літератури полегшувалося ще й порядком виписки книг із-за кордону» $[11$, с. 76]. Подібна ситуація пояснювалася тим, що царська влада вважала, і справедливо, що для більшості населення Росії події за кордоном не мали жодної ваги, а люди, що виїздили за межі імперії, були дворянами і не проголошували дійсних мотивів своєї еміграції. Так, на-приклад, видатний російський політичний діяч О. Герцен, подаючи прохання на виїзд, мотивував це необхідністю лікування своєї дружини. Як зазначала у своїх спогадах М. Рейхель, насправді «Герцену хотілося на волю, захід, в який він тоді вірив, приваблював його» [14, с. 83]. Більше того, як правило, майбутні емігранти зовсім не збиралися залишатися за кордоном надовго. Дослідник Н. Пірумова зазначала, що «залишатися надовго за кордоном, а тим більше емігрувати Герцен не збирався. Навпаки, у своїх листах він неодноразово писав друзям про свої плана швидкого повернення» [13, с. 11]. Отже, можна зробити висновок, що російські діячі, залишаючи межі імперії, не бачили в еміграції окремого способу боротьби 3 існуючим режимом, як це постає починаючи з 1860-х рр.

У своїй статті ми хотіли звернути увагу на російську еміграцію саме в Швейцарії, оскільки ця країна згодом, починаючи з 1870-х pp., стає центром всієї політичної еміграції. Перш за все підкреслимо, що в період, який нами розглядається, альпійська республіка зовсім не була тим центром, куди намагалися попасти революціонери з усієї Свропи, як це відбувалося після революції 1848 р. Потен- 
ційних політичних емігрантів приваблювали на той час в Швейцарії демократичний устрій, наявність соціалістичного руху, громадянські свободи, простота життя, а з іншого боку - прекрасна природа та цілющий клімат. Вони не думали на той час про такі принади Швейцарії як постійний нейтралітет, невидачу політичних емігрантів, можливість спілкування з революціонерами з інших країн.

Першим із відомих російських революціонерів, які прибули до Швейцарії на початку1840-х рр., став ідеолог і основоположник анархізму М. Бакунін, який поселився в Цюріху в січні 1843 р. Саме тут розпочалося його знайомство з елементами анархо-комунізму, боротьбі за який він присвятив все своє життя. М. Бакунін у своїй «Сповіді» зазначав, що «у 1843 році комунізм в Швейцарії складався з малого числа німецьких робітників у Лозанні та Женеві явно у вигляді товариств для співів, читання та для спільного господарства, в Цюріху ж... 3 п'яти чи шести кравців або шевців» [7, с. 43-44]. Саме тому місцева комуністична група була для М. Бакуніна зовсім неприваблива. Але, з іншого боку, він розпочав контакти з деякими приїжджими прихильниками комунізму з Німеччини, наприклад, Вейтлінгом. Його політична діяльність за кордоном розпочалася з написання декількох статей для газети «Швейцарський республіканець», в яких М. Бакунін активно пропагував ідеї анархізму [10, с. 69]. Так, наприклад, у статті «Комунізм» він підкреслював, що «комунізм... походить 3 народу, а з народу ніколи не може народитися тінь» [4, с. 229].

Слід зазначити, що навіть ця його незначна дія в політичній площині викликала занепокоєння російської влади. Так, представник жандармського корпусу С. Татіщев у своєму огляді революційного руху підкреслював, що «у 1843 році Бакунін поселився у Швейцарії, де зблизився з тамошніми комуністами» [15, c. 66]. У той же час російський дипломатичний представник у Берні поставив перед емігрантом вимогу повернутися до Росії, у зв'язку з чим М. Бакунін був змушений залишити Швейцарію, переїхавши до Парижа, оскільки місцева поліція надала своїм колегам із Росії всі компроментуючі матеріали на нього [10, с. 70]. У своєму листі М. Бакунін підкреслив, що «Швейцарія все-таки погана країна, яка безжально обходиться зі слабкими та беззбройними» $[4$, с. 234]. О. Герцен підкреслював, що повертатися в Росію для М. Бакуніна було неможливо, і він «відмовився підкорятися царському наказу» $[9$, с. 33]. Як зазначав один із біографів революціонера В. Андерсон, після відмови М. Бакуніна 
пове-рнутися до Росії Микола I розпорядився провести заочний суд, який позбавив дворянства і наклав арешт на його майно [2, c. 22]. Необхідно також підкреслити, що епізод, «коли швейцарський уряд відкрив товариство комуністів і прийняв серйозні заходи проти нього» [3, с. 147] можна вважати досить рідкісним фактом в історії Швейцарії. Набагато частіше, як показали наступні події 1840-90-х рр. влада країни не заперечувала проти діяльності соціалістичних організацій, що й спонукало російських, німецьких, французьких революціонерів шукати в Швейцарії політичного притулку.

Наступні роки позначилися тим, що альпійська республіка стала місцем для туризму російських підданих. Так, М. Волков, який знаходився у Цюріху та Веве в лютому 1846 р., зазначав, що «Люблю Швейцарію. Ці величезні маси граніту... вічні сніги та гігантські висоти такі граціозні...» [5, с. 313]. Вигнанці з Росії обирали для проживання інші країни та міста, переважно Париж та Лондон. Саме там відбувалися найгучніші події передреволюційного періоду, в той час як Швейцарія знаходилась осторонь від них.

Ситуація в Європі змінилася докорінним чином у 1848 р., коли розпочинаються революційні виступи в багатьох країнах. У цих умовах царський уряд був змушений вжити заходів із попередження розповсюдження в Росії, за висловом С. Шашкова, «західної зарази» [16, с. 418]. Перш за все було здійснено заходи, які б зменшували до мінімуму контакти із Західною Європою. Так, уже в березні 1848 р. було призупинено програми навчання та стажування за кордоном. 3 цього часу виїхати в європейські країни стало набагато складніше [17, с. 118]. За спогадами Н. Огарьової-Тучкової, «в цю епоху було вирішено росіян не пускати за кордон крім рідкісних випадків... серйозні хвороби, а іноземців, особливо французів, не пускати в Росію» [12, с. 53]. За даними III відділення згодом заборона на в'їзд в Росію була росповсюджена на всіх європейців [11, с. 178]. 3 іншого боку, було посилено нагляд за емігрантами з Росії з боку дипломатів та представників правоохорониих органів. Так, наприклад, у лютому 1848 р. Я. Толстой доповідав у Петербург про те, що в Парижі знаходилися російські політемігранти М. Тургенєв, І. Головін, М. Бакунін та священник Лавров [13, с. 16]. Окремим чином розпочалось посилення цензури у книговидавничій сфері.

Новий етап в еміграції до Швейцарії наступає з 1849 р., коли розпочалися процеси придушення революційних виступів, особливо 
у Франції та Німеччині. В цей час міста Цюріх, Женева, Берн, Лозанна та інші стають прихистком не тільки для російських, а й для західноєвропейських революціонерів. Такий процес дуже влучно описав О. Герцен. «Швейцарія, - зазначав він, - була тоді збірним місцем, куди сходилися з усіх сторін вцілілі залишки європейських рухів. Представники всіх невдалих революцій кочували між Женевою та Базелем» [6, с. 54]. Сюди ж приїздять і російські емігранти з розумінням, на наш погляд, того, що на довгий період саме Швейцарія стане для них тим місцем, де вони будуть у відносній безпеці від переслідувань царського уряду. В даний час саме й приходить розуміння, що еміграція - це всерйоз і надовго. Тепер, після революційних подій 1848-1849 рр., було необхідно не просто ховатися від можливих репресій, але й розпочинати антимонархічну діяльність саме із-за меж імперії. Дослідник історії царських каральних органів М. Лемке підкреслював, що, повернувшись до Женеви із Парижа, емігрант I. Головін започаткував видавництво російською мовою. Першою було видано брошуру «Катехізис російського народу», при чому місцем видавництва спеціально було вказано Петербург, типографія імені Павловича. Цікавим, з нашої точки зору, є наступна теза, викладена в «Катехізисі», де, говорячи про еміграцію, І. Головін зазначав, що «нас вигнали за кордон, а коли ми повернулися до вас із запасом вченості ваші управителі відкрили по нам вогонь переслідування» [8, с. 36].

Якщо говорити в цілому, то після 1848 р. в різних містах Швейцарії проживали видатні діячі російського та європейського революційних рухів, як то: Ф. Енгельс, О. Герцен, М. Бакунін та багато інших. Важивим видається те, що саме під час дискусій про причини поразки вдавалося не лише проаналізувати невдачі, але й намітити шляхи розвитку майбутніх революцій. Федеральний швецарський уряд не насмілився вигнати емігрантів із країни, що дало можливість і в майбутньому розраховувати на притулок у цій альпійській республіці. Необхідно вказати, що в різні часи в Швейцарії проживали Ф. Енгельс, Е. Бернштейн, Д. Мадзіні, О. Бланкі, Е. Реклю, П. Кропоткін, П. Лавров, Г. Плеханов, Ю. Мартов, В. Ленін, В. Чернов, М. Гоц, М. Драгоманов та ін. Якщо говорити про російську еміграцію, то саме в Женеві та Цюріху видавалися провідні революційні назети та журнали «Колокол», «Вперед», «Набат», «Іскра», «Пролетарій», «Революційна Росія», «Хліб і Воля». Урешті-решт на початку ХХ ст. радикальні партії та оранізації змогли створити на базі Швейцарії таке унікальне явище, як закордонна операційна база, че- 
рез яку активно впливали на події в Російські імперії. Царські правоохоронні органи виявилися безсилими у боротьбі з емігрантами, велика заслуга яких полягала у сприянні підготовки революцій в Росії.

Отже, початковий період 1840-х рр. не пройшов марно для російської революційної еміграції. Саме в цей час було закладено підвалини діяльності в еміграції взагалі, встановлено перші контакти 3 міжнародним соціалістичним рухом, отримано досвід роботи поза межами Росії. Також необхідно зазначити, що перші політичні емігранти Герцен, Головін, Бакунін, Сазонов залишилися за кордоном, не повернувшись на батьківщину, тобто для них еміграція стала незворотнім явищем на відміну від більш пізніх часів, коли подібний вид еміграція перетворюється на маятниковий тип,за якого існує постійний взаємозв'язок між країною походженя та країною перебування. Поступово емігранти 1840-х рр. виявилися відірваними від російської дійсності, перестаючи бути авторитетними для революціонерів у Росії. Цей процес припиняється лише у 1870-х рр., коли російські студенти, набувши вищої освіти в швейцарських університетах та революційної освіти у лідерів радикальних течій, повернулися на батьківщину, ставши активними учасниками «ходіння в народ».

\section{БІБЛІОГРАФІЧНІ ПОСИЛАННЯ}

1. Анненков П. В. Литературные воспоминания / П. В. Анненков. - М.: Художественная литература, 1983. - 694 с.

2. Андерсон В. М. М. А. Бакунин / В. М. Андерсон. - СПб.: Труд и польза, 1906. -72 с.

3. Бакунин (новые материалы) // Красный архив. - 1926. - Т. 4. - № 17. - С. 138-155.

4. Бакунин М. А. Собрание сочинений и писем. 1828-1876 / М. А. Бакунин. - М.: Издво Всесоюзного общества политкаторжан и ссыльно-поселенцев, 1935. - Т. 3.- 572 с.

5. Волков М. Отрывки из заграничных писем (1844-1848) / М. Волков. - СПб.: Типография Императорской Академии Наук, 1857. - 552 с.

6. Герцен А. И. Былое и думы. Собр. соч.: у 8 т. / А. И. Герцен. - М.: Правда, 1975. - T. 7. $-607 \mathrm{c}$.

7. Бакунин М. А. Исповедь / М. А. Бакунин // Материалы для биографии М. Бакунина. - М.; СПб: Госиздат, 1923. - Т. 1. - 439 с.

8. Лемке М. К. Эмигрант Иван Головин (По неизданным материалам) / М. К. Лемке // Былое. - 1907. - № 5. - С. 24-52.

9. Неизданное письмо Герцена к Мишле // Былое. - 1907. - № 7. - С. 29-39.

10. Неттлау М. Бакунин / М. Неттлау / Очерки анархического движения в России. - М.: Голос труда, 1926. - С. 58-130.

11. Нифонтов А. С. 1848 год в России: Очерки по истории 40-х годов / А. С. Нифонтов. - М.; Л.: Госсоцэкгиз, 1931. - 208 с.

12. Огарева-Тучкова Н. А. Записки Наталии Алексеевны Огаревой-Тучковой / Н. А. Огарева-Тучкова // Русская старина. - 1890. - Т. 68. - С. 1-80. 
13. Пирумова Н. М. Александр Герцен - революционер, мыслитель, человек / Н. М. Пирумова. - М.: Мысль, 1989. - 254 с.

14. Рейхель М. К. Отрывки из воспоминаний М. К. Рейхель и письма к ней А. И. Герцена / М. К. Рейхель. - М.: Издание Л. Э. Бухгейм, 1909. - 128 с.

15. Татищев С. С. Револиюционное движение в России. 1861-1881 гг. Записка, составленная по Департаменту полици / С. С. Татищев. - Б.м., б.г. -310 с.

16. Шашков С. С. Русские реакции / Собр. соч. С. С. Шашкова. - Т. 2, кн. 4 / С. С. Шашков. - СПб.: Издание О. Н. Поповой, 1898. - С. 225-442.

17. Эпоха Николая I / Под ред. М. О. Гершензона. - М.: Издание Книгоиздательского товарищества «Образование», 1910. - 187 с.

Надійшла до редкол.: 14.03.2018

УДК : 94 : $329(477.4+470+571) \ll 18 / 19 »$

DOI: $10.15421 / 23183$

\section{Ставлення та дії верхівки Російської імперії щодо українських політичних партій у Наддніпрянщині наприкінці XIX - початку XX ст. \\ Сарнацький О. П. \\ Запорізький національний технічний університет}

Висвітлено ставлення та дії царя і центральної влади Російської імперії щодо діяльності політичних сил, які очолювали український національно-визвольний рух у Наддніпрянщині наприкінці XIX - початку XX ст.

Ключові слова: центральна влада; губернатор; генерал-губернатор; Південно-Західний край; циркуляри; накази; українські політичні партії; репресії

Освещено отношение и действия царя и центральной власти Российской империи относительно деятельности политических сил, которые возглавляли украинское национально-освободительное движение в Приднепровье в конце XIX - начале XX вв.

Ключевые слова: центральная власть; губернатор; генерал-губернатор; Юго-Западний край; циркуляры; приказы; украинские политические партии; репрессии

In this article, based on the publications of domestic researchers, whose works continue to be the main components of the subject matter, as well as pre-revolutionary archival sources, the author highlights the attitude and actions of the tsar and central government of the Russian Empire as to the activities of the political forces that headed Ukrainian national-liberation movement in the Naddnieprianschina in the late nineteenth and early twentieth centuries. Governors, as part of the Ministry of Internal Affairs, were responsible for execution of all orders and circular letters. At the same time, similar, at the first glance, the mediation of the circular letters and the directions of the Ministry of Internal Affairs as to everything related to the Ukrainian nationalliberation movement and the Ukrainian political parties is conditional and ghostly. 